\title{
OPTIMIZATION OF ZINC REMOVAL FROM SIMULATED WASTEWATER USING CEMENT KILN DUST (CKD) AS ADSORBENT
}

\section{${ }^{*}$ Hanan A.Ibraheem ${ }^{1}$}

1) University of Al-Qadisiyah, Qadisiyah ,Iraq

2) University of Al-Qadisiyah, Qadisiyah ,Iraq

\begin{abstract}
Zinc removal from simulated wastewater was achieved using cement kiln dust an adsorbent material. Effects of contact time, $\mathrm{pH}$, zinc ion concentration, rotational speed, and amount of CKD were investigated.

The best operating conditions were determined via application of response surface methodology. Results showed that zinc concentration has the main effect on zinc removal efficiency followed by time, shaking, CKD dosage and $\mathrm{pH}$. The best operating conditions were found to be $\mathrm{pH}$ value equal to 8 , contact time of 90 minutes, rotational speed of $300 \mathrm{rpm}$, zinc ion concentration of $20 \mathrm{ppm}$ and the amount of cement kiln dust (CKD) equal to $35 \mathrm{~g} \backslash \mathrm{L}$. based on these optimum condition, $99.37 \%$ zinc removal efficiency was obtained.
\end{abstract}

Keywords: CKD, Waste water,Zinc removal,Response surface methodology

\section{Introduction}

Due to the increase in human activities represented by industries, mining operations and household needs, there is an increased demand for water use, at the same time it has become an increase in the production of wastewater in general and in particular industrial wastewater resulting from manufacturing processes that are loaded with many pollutants, especially pollutants of inorganic materials represented by heavy metals like zinc which is the most dangerous among them as it causes many

\author{
Husham M.Al.Tameemi ${ }^{2}$
}

diseases such as cancer because it accumulates inside the bodies of living organisms [1, 2, 3].

Therefore, the scientists resorted to find ways to get rid of these minerals and treat the problem of water pollution. Several methods were used to remove of zinc, including electro deposition, [4] adsorption [5], reverse osmosis, ion exchange, deposition $[6,7,8]$, etc.

But these methods were costly and not efficient High. Therefore, the researchers continued their attempts to find methods that are economical and highly efficient and by using materials available in the environment.

Cement kiln dust (CKD) material is one of those materials. it is a byproduct material resulting from cement manufacturing operations that have a basic characteristic and its particles are very small $[9,10,11]$.

It produces at a rate of $3-5 \%$ of cement production [1], as it produces almost 800,000 tons annually in Iraq.

Its presence causes pollution to the environment because they affect the respiratory system of a person. It uses in many operations, including 
stabilizing the soil [12], production of fertilizers building materials and as an absorbent [13, 14, 15, and 16].

Present work aims to examine the ability of a locally produced CKD as an absorbent to remove of zinc from wastewater. Response surface methodology was adopted to get the best operating conditions

$\begin{array}{ll}\text { Abbreviations } \\ \text { RSM } & \text { Response surface methodology } \\ \text { BBD } & \text { Box-Behnken Design } \\ \text { CKD } & \text { cement kiln dust } \\ \text { t } & \text { time, s } \\ \text { Zn } & \text { Zinc } \\ \text { X1 } & \text { Concentration of CKD ,g/l } \\ \text { X2 } & \text { Concentration of zinc, ppm } \\ \text { X3 } & \text { Shaking rate, rpm } \\ \text { X5 } & \text { pH } \\ \text { X4 } & \text { Contact time, min } \\ \text { x1 } & \text { coded value of zinc Concentration } \\ \text { x2 } & \text { coded value of ckd Concentration } \\ \text { x3 } & \text { coded value of shaking rate } \\ \text { x4 } & \text { coded value of pH } \\ \text { x5 } & \text { coded value of contact time } \\ \text { ao } & \text { The code of intercept } \\ \text { ai } & \text { The first-class(linear) major effect } \\ \text { aii } & \text { Second-class major effect } \\ \text { aij } & \text { The interaction effect } \\ \text { cp } & \text { Confidence interval } \\ \text { CI } & \text { Reiterated number of the central } \\ \text { PI } & \text { Prediction interval. } \\ \text { ANOVA } & \text { Analysis of variance } \\ \text { DOF } & \text { Degree of freedom } \\ \text { DF } & \text { The desirability function } \\ \text { Seq. SS } & \text { Sum of square } \\ \text { Cr. \% } & \text { Percentage contribution for each } \\ \text { Adj. MS } & \text { Adjusted mean of the square } \\ \text { Adj. SS } & \text { Adjusted sum of the square } \\ \text { adj. R2 } & \text { Adjusted coefficient of multiple } \\ \text { pred. R2 } & \text { Predicted multiple correlation } \\ \text { RE } & \text { Removal Efficiency (\%) } \\ \text { k } & \text { Number of process variables } \\ \text { S } & \text { Standard Error of the Regression } \\ & \end{array}$

Number of runs

SE Standard error of mean

N Represents the dependent variable

\section{Materials and Methods}

\subsection{Cement kiln dust characterization}

Two kg of CKD was taken from Al-Duh Cement Factory located south of Al-Muthanna Governorate. Show in figure (1).

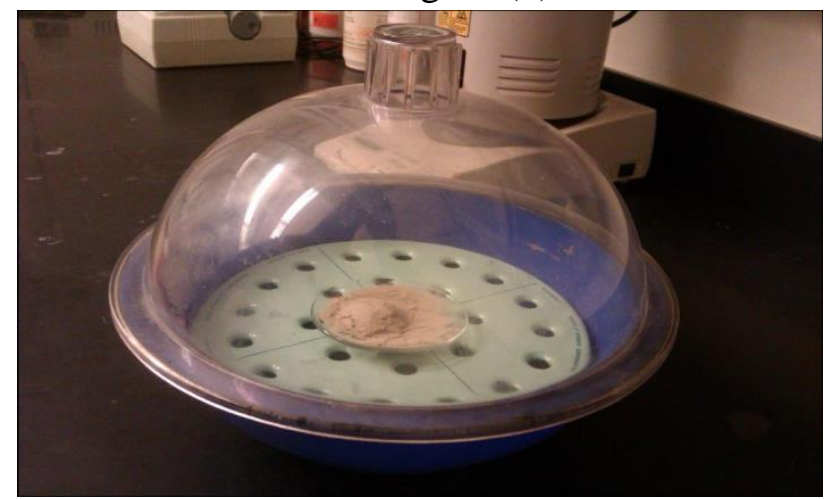

Figure (1): Material of CKD

The material was dried in a laboratory oven at a temperature of $100{ }^{\circ} \mathrm{C}$. X-ray diffraction (XRD) and Energy-dispersive X-ray spectroscopy (EDX) examination was performed in the laboratories of the Ministry of Science and Technology / Materials Research Department in Baghdad using (A Philips X-ray diffraction analyzer Spectrometer (equipment model PW/1710 with Monochromator 2009)).

\section{2. preparation of zinc solution}

Zinc sulfate $\left(\mathrm{ZnSO}_{4} .7 \mathrm{H}_{2} \mathrm{O}\right)$ was used for prefer take 3 concentration for obtain accuracy concentrations (20, 60 and $100 \mathrm{ppm})$ by dissolving the $(0.035,0.105$ and 0.176$) \mathrm{gm}$. respectively in $400 \mathrm{ml}$ of distilled water. $\mathrm{pH}$ of solution was adjusted using $0.1 \mathrm{M} \mathrm{NaOH}$ and/or $0.1 \mathrm{M} \mathrm{HCl}$. the required amount of $\mathrm{CKD}$ was then added at concentrations $(5,20$ and 35) $\mathrm{g} / 1$ to the zinc solution then shaking the resulted solution at a different rotation rate (100, 200 and 300rpm) and different times (30, 60, and 90 minutes). 
After completing the adsorption process the solution was filtered then sample $(5 \mathrm{~mL})$ was taken for determine the residue concentration of zinc by atomic absorption technique. All experiments were conducted at room temperature in duplicate and therefore the average values were considered for data analysis.

The removal efficiency ( $\mathrm{R} \%$ ) of the cement kiln dust on zinc was calculated in line with the subsequent formula (Eq. 1) :

$R \%=\frac{\left(C_{0}-C\right)}{C_{0}} * 100$

Where $\mathrm{C}_{0}$ in $(\mathrm{g} / \mathrm{l})$ is the initial concentration of the zinc solution and $\mathrm{C}$ in $(\mathrm{g} / \mathrm{l})$ is that the final concentration of the zinc solution.

\subsection{Design of experiments}

Box - Behnken enhances designs to urge the acceptable quadratic model with the desired statistical properties using only one element of the runs required for a factorial of 3 levels. The quantity of runs $(\mathrm{N})$ needed to execute the Box - Behnken design is calculated by the following equation (2):

$N=2 K(K-1)+c p$

Where $\mathrm{k}$ is the number of process variables and $\mathrm{cp}$ is the reiterated number of the central point.In this research, forty six runs were conducted for evaluating the effects of the process variables on the zinc removal efficiency [17]. (Table 2) illustrates the BBD proposed for the present research.A second orders polynomial model can be adopted based on BBD where fitting the interaction terms with the experimental data can be described by the following equation (3):

$\mathrm{Y}=\mathrm{a}_{0}+\sum \mathrm{a}_{\mathrm{i}} \mathrm{x}_{\mathrm{i}}+\sum \mathrm{a}_{\mathrm{ii}} \mathrm{x}_{\mathrm{i}}^{2}+\sum \mathrm{a}_{\mathrm{ij}} \mathrm{x}_{\mathrm{i}} \mathrm{x}_{\mathrm{j}}$

Where $\mathrm{Y}$ represents the variable $(\mathrm{RE}), \mathrm{i}$ and $\mathrm{j}$ are the index numbers for patterns, $\mathrm{a}_{0}$ is intercept term, $\mathrm{x}_{1}, \mathrm{x}_{2} \ldots \mathrm{x}_{\mathrm{k}}$ are the method variables (independent variables) in coded form $a_{i}$ is the first-order (linear) main effect, $a_{i i}$ second-order main effect and $\mathrm{a}_{\mathrm{ij}}$ is that the interaction effect.

Analysis of variance was performed then the parametric statistic (R2) was estimated to verify the goodness of model fit. A group of mathematical and statistical techniques adopted by RSM [18] will determine the relation between a process response and its variables. The 3-level 5-factor Box - Behnken experimental design is introduced during this study to verify and test the variables affecting zinc removal from simulated wastewater [19].

Initial zinc ion concentration (X1) CKD dosage $(\mathrm{g} / \mathrm{l})(\mathrm{X} 2)$, Shaking rate $(\mathrm{rpm})(\mathrm{X} 3), \mathrm{pH}$ value (X4), and speak to time (min) (X5) were taken as process variables, while the efficiency of zinc removal was taken as a response. The scales of process variables were coded as -1 (low level), 0 (middle or central point) and 1 (high level) [20]. (Table 1) illustrates the method variables with their chosen levels.

Table 1. Process variables with their level for Zinc removal

\begin{tabular}{|l|l|l|l|}
\hline Process parameters & \multicolumn{2}{l|}{ range in Box-Behnken design } \\
\hline Coded levels & Low(-1) & Middle(0) & High(+1) \\
\hline X1- Initial conc. (ppm) & 20 & 60 & 100 \\
\hline X2- CKD dosage(g/l) & 5 & 20 & 35 \\
\hline X3- Shaking rate(rpm) & 100 & 200 & 300 \\
\hline X4-pH value & 2 & 5 & 8 \\
\hline X5-Contact time(min) & 30 & 60 & 90 \\
\hline
\end{tabular}

Table 2 .Box- Behnken experimental design 


\begin{tabular}{|c|c|c|c|c|c|c|c|c|c|c|c|}
\hline \multirow{2}{*}{$\underset{\Sigma}{\Xi}$} & \multirow{2}{*}{$\begin{array}{l}\frac{y}{u} \\
\frac{0}{n} \\
\end{array}$} & \multicolumn{5}{|c|}{ Coded value } & \multirow{2}{*}{ 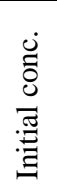 } & \multirow{2}{*}{ 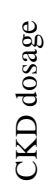 } & \multirow{2}{*}{ 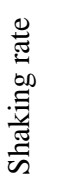 } & \multirow{2}{*}{$\frac{\pi}{2}$} & \multirow{2}{*}{ 芯 } \\
\hline & & $\bar{x}$ & $x$ & $\tilde{x}$ & $\underset{X}{\Delta}$ & 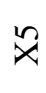 & & & & & \\
\hline 1 & 1 & $1-$ & 1 & 0 & 0 & 0 & 20 & 35 & 200 & 5 & 60 \\
\hline 2 & 1 & 0 & 1 & $1-$ & 0 & 0 & 60 & 35 & 100 & 5 & 60 \\
\hline 3 & 1 & 0 & 1 & 0 & 0 & 1 & 60 & 35 & 200 & 5 & 90 \\
\hline 4 & 1 & 0 & 1 & 0 & $1-$ & 0 & 60 & 35 & 200 & 2 & 60 \\
\hline 5 & 1 & 0 & 0 & 1 & 0 & 1- & 60 & 20 & 300 & 5 & 30 \\
\hline 6 & 1 & 1 & 0 & 1 & 0 & 0 & 10 & 20 & 300 & 5 & 60 \\
\hline 7 & 1 & 0 & 0 & 0 & 1 & $1-$ & 60 & 20 & 200 & 8 & 30 \\
\hline 8 & 1 & 0 & 0 & 1 & $1-$ & 0 & 60 & 20 & 300 & 2 & 60 \\
\hline 9 & 1 & 0 & 0 & 0 & 0 & 0 & 60 & 20 & 200 & 5 & 60 \\
\hline 10 & 1 & 0 & 1 & 0 & $1-$ & 0 & 60 & 5 & 200 & 2 & 60 \\
\hline 11 & 1 & 0 & 0 & 0 & $1-$ & 1 & 60 & 20 & 200 & 2 & 90 \\
\hline 12 & 1 & $1-$ & 0 & 1- & 0 & 0 & 20 & 20 & 100 & 5 & 60 \\
\hline 13 & 1 & 0 & 0 & 1 & 1 & 0 & 60 & 20 & 300 & 8 & 60 \\
\hline 14 & 1 & 0 & 0 & 1 & 0 & 1 & 60 & 20 & 300 & 5 & 90 \\
\hline 15 & 1 & 1- & 0 & 0 & $1-$ & 0 & 20 & 20 & 200 & 2 & 60 \\
\hline 16 & 1 & 0 & 0 & 0 & $1-$ & $1-$ & 60 & 20 & 200 & 2 & 30 \\
\hline 17 & 1 & 0 & 0 & 1- & 0 & $1-$ & 60 & 20 & 100 & 5 & 30 \\
\hline 18 & 1 & $1-$ & 0 & 0 & 1 & 0 & 20 & 20 & 200 & 8 & 60 \\
\hline 19 & 1 & 1 & 0 & 0 & 0 & $1-$ & $\begin{array}{c}10 \\
0\end{array}$ & 20 & 200 & 5 & 30 \\
\hline 20 & 1 & 0 & 1 & 0 & 0 & 1 & 60 & 35 & 200 & 5 & 30 \\
\hline
\end{tabular}

\begin{tabular}{|c|c|c|c|c|c|c|c|c|c|c|c|}
\hline 21 & 1 & 0 & 0 & 0 & 0 & 0 & 60 & 20 & 200 & 5 & 60 \\
\hline 22 & 1 & 0 & $1-$ & 1 & 0 & 0 & 60 & 5 & 300 & 5 & 60 \\
\hline 23 & 1 & $1-$ & 0 & 1 & 0 & 0 & 20 & 20 & 300 & 5 & 60 \\
\hline 24 & 1 & 0 & 0 & 0 & 0 & 0 & 60 & 20 & 200 & 5 & 60 \\
\hline 25 & 1 & 0 & 0 & 0 & 0 & 0 & 60 & 20 & 200 & 5 & 60 \\
\hline 26 & 1 & 0 & 0 & $1-$ & 1 & 0 & 60 & 20 & 100 & 8 & 60 \\
\hline 27 & 1 & 0 & 1 & 0 & 1 & 0 & 60 & 35 & 200 & 8 & 60 \\
\hline 28 & 1 & 0 & 1 & 1 & 0 & 0 & 60 & 35 & 300 & 5 & 60 \\
\hline 29 & 1 & 1 & 0 & 0 & 1 & 0 & 100 & 20 & 200 & 8 & 60 \\
\hline 30 & 1 & $1-$ & 0 & 0 & 0 & 1 & 20 & 20 & 200 & 5 & 90 \\
\hline 31 & 1 & 1- & 0 & 0 & 0 & 1- & 20 & 20 & 200 & 5 & 30 \\
\hline 32 & 1 & 1 & 0 & 0 & $1-$ & 0 & 100 & 20 & 200 & 2 & 60 \\
\hline 33 & 1 & 0 & $1-$ & 0 & 0 & $1-$ & 60 & 5 & 200 & 5 & 30 \\
\hline 34 & 1 & 1 & 0 & $1-$ & 0 & 0 & 100 & 20 & 100 & 5 & 60 \\
\hline 35 & 1 & 0 & $1-$ & 0 & 0 & 1 & 60 & 5 & 200 & 5 & 90 \\
\hline 36 & 1 & $1-$ & $1-$ & 0 & 0 & 0 & 20 & 5 & 200 & 5 & 60 \\
\hline 37 & 1 & 0 & $1-$ & 0 & 1 & 0 & 60 & 5 & 200 & 8 & 60 \\
\hline 38 & 1 & 0 & 0 & $1-$ & $1-$ & 0 & 60 & 20 & 100 & 2 & 60 \\
\hline 39 & 1 & 0 & 0 & 0 & 0 & 0 & 60 & 20 & 200 & 5 & 60 \\
\hline 40 & 1 & 1 & 1 & 0 & 0 & 0 & 100 & 35 & 200 & 5 & 60 \\
\hline 41 & 1 & 0 & 0 & $1-$ & 0 & 1 & 60 & 20 & 100 & 5 & 90 \\
\hline 42 & 1 & 1 & 0 & 0 & 0 & 1 & 100 & 20 & 200 & 5 & 90 \\
\hline 43 & 1 & 0 & $1-$ & $1-$ & 0 & 0 & 60 & 5 & 100 & 5 & 60 \\
\hline 44 & 1 & 0 & 0 & 0 & 0 & 0 & 60 & 20 & 200 & 5 & 60 \\
\hline 45 & 1 & 1 & $1-$ & 0 & 0 & 0 & 100 & 5 & 200 & 5 & 60 \\
\hline 46 & 1 & 0 & 0 & 0 & 1 & 1 & 60 & 20 & 200 & 8 & 90 \\
\hline
\end{tabular}




\section{Results and discussion}

\subsection{CKD properties}

$\mathrm{XRD}$ analysis of CKD was done as show in figure (2) in the target was copper $(\lambda=$ $1.5406 \mathrm{~A}^{\circ}$ ) at $40 \mathrm{kV}, 30 \mathrm{~mA}$, and the scanning speed was 5॰ min-1. The reflection peaks between $2 \theta=5^{\circ}$ and $80^{\circ}$, corresponding spacing $\left(\mathrm{d}, \mathrm{A}^{\circ}\right)$, present time (0.6 s) and relative intensities (I/Io) were obtained table (3).

Table3. The chemical composition of CKD (this study)

\begin{tabular}{|l|l|}
\hline Components & Average \% \\
\hline $\mathrm{CaO}$ & 47.81 \\
\hline $\mathrm{SiO}_{2}$ & 17.3 \\
\hline $\mathrm{So}_{3}$ & 11.98 \\
\hline $\mathrm{K}_{2} \mathrm{O}$ & 4.9 \\
\hline $\mathrm{Al}_{2} \mathrm{O}_{3}$ & 3.7 \\
\hline $\mathrm{Fe}_{2} \mathrm{O}_{3}$ & 2.6 \\
\hline $\mathrm{MgO}$ & 2.5 \\
\hline $\mathrm{L} . \mathrm{O} . \mathrm{I}$ & 9.21 \\
\hline
\end{tabular}

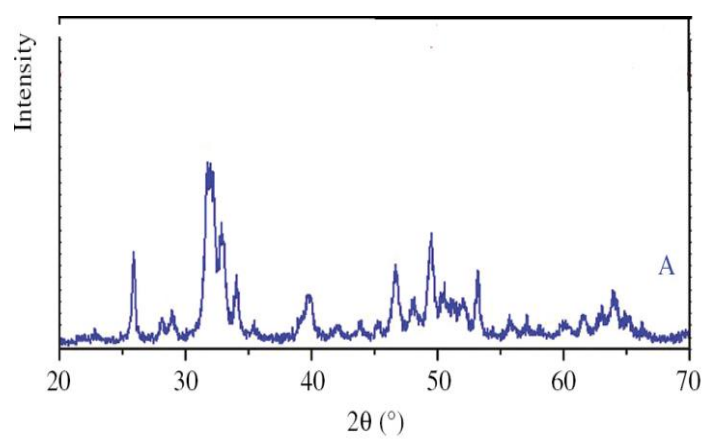

Figure (2): XRD for CKD

\subsection{Statistical analysis}

In order to optimize the assembly of a specific material by optimizing operational variables, statistical methods such as RSM are used.
The interaction between process variables is determined by statistical techniques, as opposed to traditional methods [1].

Forty-six tests were carried out in various groups with different variables of the method to determine its effect on the removal ratios and the knowledge of their optimization.

For each experiment Table 4 shows the removal values. This table includes the current and expected efficiencies. It is interesting to note that, upon approval of the experimental design, the efficiency of zinc removal was changed from 31.34 to 99.37 percent.

Table (4) Experimental results Zinc removal

\begin{tabular}{|c|c|c|c|c|c|c|c|c|}
\hline \multirow[b]{2}{*}{$\cong$} & \multirow{2}{*}{$\begin{array}{l}\frac{n}{\Delta} \\
\frac{0}{n}\end{array}$} & \multirow[b]{2}{*}{$\bar{x}$} & \multirow[b]{2}{*}{$\tilde{x}$} & \multirow[b]{2}{*}{$\tilde{x}$} & \multirow[b]{2}{*}{$\underset{x}{\Delta}$} & \multirow[b]{2}{*}{$\ddot{x}$} & \multicolumn{2}{|l|}{ RE\% } \\
\hline & & & & & & & $\begin{array}{l}\text { Actu } \\
\text { al }\end{array}$ & $\begin{array}{l}\text { Predicti } \\
\text { on }\end{array}$ \\
\hline 1 & 1 & 20 & 35 & $\begin{array}{l}20 \\
0\end{array}$ & 5 & 60 & 99.37 & 96.06 \\
\hline 2 & 1 & 60 & 35 & $\begin{array}{l}10 \\
0\end{array}$ & 5 & 60 & 48.27 & 47.10 \\
\hline 3 & 1 & 60 & 35 & $\begin{array}{l}20 \\
0\end{array}$ & 5 & 90 & 56.37 & 44.13 \\
\hline 4 & 1 & 60 & 35 & $\begin{array}{l}20 \\
0\end{array}$ & 2 & 60 & 40.08 & 58.72 \\
\hline 5 & 1 & 60 & 20 & $\begin{array}{l}30 \\
0\end{array}$ & 5 & 30 & 45.55 & 48.02 \\
\hline 6 & 1 & $\begin{array}{l}10 \\
0\end{array}$ & 20 & $\begin{array}{l}30 \\
0\end{array}$ & 5 & 60 & 44.48 & 44.38 \\
\hline 7 & 1 & 60 & 20 & $\begin{array}{l}20 \\
0\end{array}$ & 8 & 30 & 41.4 & 43.34 \\
\hline 8 & 1 & 60 & 20 & $\begin{array}{l}30 \\
0\end{array}$ & 2 & 60 & 49.43 & 46.89 \\
\hline 9 & 1 & 60 & 20 & $\begin{array}{l}20 \\
0\end{array}$ & 5 & 60 & 45.8 & 46.63 \\
\hline 10 & 1 & 60 & 5 & $\begin{array}{l}20 \\
0\end{array}$ & 2 & 60 & 38.83 & 38.96 \\
\hline 11 & 1 & 60 & 20 & $\begin{array}{l}20 \\
0\end{array}$ & 2 & 90 & 55.84 & 51.70 \\
\hline 12 & 1 & 20 & 20 & $\begin{array}{l}10 \\
0\end{array}$ & 5 & 60 & 94.28 & 92.04 \\
\hline 13 & 1 & 60 & 20 & $\begin{array}{l}30 \\
0\end{array}$ & 8 & 60 & 55.3 & 55.53 \\
\hline
\end{tabular}




\begin{tabular}{|l|l|l|l|l|l|l|l|l|}
\hline 14 & 1 & 60 & 20 & 300 & 5 & 90 & 63.67 & 63.20 \\
\hline 15 & 1 & 20 & 20 & 200 & 2 & 60 & 83.29 & 88.52 \\
\hline 16 & 1 & 60 & 20 & 200 & 2 & 30 & 33.9 & 36.30 \\
\hline 17 & 1 & 60 & 20 & 100 & 5 & 30 & 33.78 & 34.06 \\
\hline 18 & 1 & 20 & 20 & 200 & 8 & 60 & 93.91 & 95.36 \\
\hline 19 & 1 & $\begin{array}{l}10 \\
0\end{array}$ & 20 & 200 & 5 & 30 & 27.67 & 46.63 \\
\hline 20 & 1 & 60 & 35 & 200 & 5 & 30 & 48.49 & 46.82 \\
\hline 21 & 1 & 60 & 20 & 200 & 5 & 60 & 45.92 & 27.52 \\
\hline 22 & 1 & 60 & 5 & 300 & 5 & 60 & 46.59 & 48.36 \\
\hline 23 & 1 & 20 & 20 & 300 & 5 & 60 & 95.92 & 46.63 \\
\hline 24 & 1 & 60 & 20 & 200 & 5 & 60 & 47.2 & 95.13 \\
\hline 25 & 1 & 60 & 20 & 200 & 5 & 60 & 46.63 & 46.63 \\
\hline 26 & 1 & 60 & 20 & 100 & 8 & 60 & 44.1 & 42.66 \\
\hline 27 & 1 & 60 & 35 & 200 & 8 & 60 & 52.96 & 56.56 \\
\hline 28 & 1 & 60 & 35 & 300 & 5 & 60 & 57.17 & 56.24 \\
\hline 29 & 1 & 10 & 20 & 200 & 8 & 60 & 42.75 & 46.63 \\
\hline 30 & 1 & 20 & 20 & 200 & 5 & 90 & 98.25 & 42.66 \\
\hline 31 & 1 & 20 & 20 & 200 & 5 & 30 & 90.01 & 56.56 \\
\hline 32 & 1 & $\begin{array}{l}10 \\
2\end{array}$ & 20 & 200 & 2 & 60 & 31.51 & 32.81 \\
\hline 33 & 1 & 60 & 5 & 200 & 5 & 30 & 35.34 & 33.08 \\
\hline 34 & 1 & 10 & 20 & 100 & 5 & 60 & 26.25 & 28.35 \\
\hline 35 & 1 & 60 & 5 & 200 & 5 & 90 & 50.44 & 52.20 \\
\hline 36 & 1 & 20 & 5 & 200 & 5 & 60 & 91.5 & 90.32 \\
\hline 37 & 1 & 60 & 5 & 200 & 8 & 60 & 41.8 & 41.16 \\
\hline 38 & 1 & 60 & 20 & 100 & 2 & 60 & 41.22 & 37.00 \\
\hline 39 & 1 & 60 & 20 & 200 & 5 & 60 & 46.1 & 46.63 \\
\hline 40 & 1 & $\begin{array}{l}10 \\
0\end{array}$ & 35 & 200 & 5 & 60 & 47.99 & 45.05 \\
\hline 41 & 1 & 60 & 20 & 100 & 5 & 90 & 45.3 & 50.73 \\
\hline 42 & 1 & $\begin{array}{l}10 \\
0\end{array}$ & 20 & 200 & 5 & 90 & 51.3 & 48.52 \\
\hline 43 & 1 & 60 & 5 & 100 & 5 & 60 & 33.85 & 35.05 \\
\hline 44 & 1 & 60 & 20 & 200 & 5 & 60 & 48.14 & 46.63 \\
\hline 45 & 1 & 10 & 5 & 200 & 5 & 60 & 31.34 & 56.72 \\
\hline 46 & 1 & 60 & 20 & 200 & 8 & 90 & 59.08 & 30.53 \\
\hline
\end{tabular}

Table 5. Analysis of variance for zinc removal

\begin{tabular}{llllllll}
\hline Source & DF & $\begin{array}{l}\text { Seq } \\
\text { SS }\end{array}$ & Cr\% & $\begin{array}{l}\text { Adj } \\
\text { SS }\end{array}$ & $\begin{array}{l}\text { Adj } \\
\text { MS }\end{array}$ & $\begin{array}{l}\text { F- } \\
\text { valu } \\
\text { e }\end{array}$ & $\begin{array}{l}\text { P- } \\
\text { val } \\
\text { ue }\end{array}$ \\
\hline Model & 20 & 183 & 98.8 & 183 & 919. & 110. & 0.0
\end{tabular}

$87.2 \quad 8 \% \quad 87.2 \quad 4 \quad 49 \quad 00$

$\begin{array}{llllllll}\text { Linear } & 5 & 143 & 77.3 & 143 & 287 & 345 . & 0.0 \\ & & 74.5 & 0 \% & 74.5 & 4.9 & 52 & 00\end{array}$

$\mathrm{X} 1$

$\begin{array}{llllll}122 & 66.0 & 122 & 122 & 147 & 0.0\end{array}$

$\begin{array}{llllll}78.9 & 3 \% & 78.9 & 78.9 & 5.74 & 00\end{array}$

$\mathrm{X} 2$

$\begin{array}{llllll}\text { 410. } & 2.21 & 410 . & 410 . & 49.3 & 0.0\end{array}$

$2 \quad \% \quad 2 \quad 2 \quad 000$

$\mathrm{X} 3$

518. $2.79 \quad 518 . \quad 518 . \quad 62.2 \quad 0.0$

$\begin{array}{llllll}2 & \% & 2 & 2 & 9 & 00\end{array}$

$\mathrm{X} 4$

204. $1.1 \%$ 204. 204. 24.5 0.0

$\begin{array}{llllll}5 & 1.1 \% & 5 & 5 & 8 & 00\end{array}$

X5

962. $5.18 \quad 962 . \quad 962 . \quad 115.0 .0$ $\begin{array}{llllll}7 & \% & 7 & 7 & 70 & 00\end{array}$

$\begin{array}{llllllll}\text { Square } & 5 & 380 & 20.4 & 380 & 761 . & 91.4 & 0.0 \\ & 6.4 & 7 \% & 6.4 & 3 & 9 & 00\end{array}$

$\begin{array}{lllllll}\mathrm{X}^{2} & 376 & 20.2 & 314 & 314 & 378 & 0.0\end{array}$ $\begin{array}{llllll}5.1 & 5 \% & 7.4 & 7.4 & 27 & 00\end{array}$

0.8

$\begin{array}{lllllll}1 & 0.2 & 0.0 \% & 0.1 & 0.1 & 0.2 & 96\end{array}$

$\begin{array}{llllll}\mathrm{X}^{2} & & 0.7\end{array}$

$\begin{array}{lllllll}1 & 0.9 & 0.0 \% & 0.6 & 0.6 & 0.8 & 85\end{array}$

\begin{tabular}{ll|l|l|l}
$\mathrm{X} 4^{2}$ & 0.15 & 0.1
\end{tabular}

$\begin{array}{lllllll}1 & 27.5 & \begin{array}{lll}0.15 \\ \%\end{array} & 16.6 & 16.6 & 1.99 & 71\end{array}$

$\mathrm{X} 5^{2}$

$\begin{array}{lllllll}1 & 12.7 & \begin{array}{l}0.07 \\ \%\end{array} & 12.7 & 12.7 & 1.52 & 29\end{array}$

$\begin{array}{llllll}2 \text {-Way } & 206 . & 1.11 & 206 . & 0.0\end{array}$ $\begin{array}{llllllll}\text { Interac } & 10 & 206 . & 1.11 & 206 . & 20.6 & 2.48 & 32\end{array}$ tion

$\mathrm{X} 1 * \mathrm{X} 2$

0.1

$\begin{array}{lllllll}1 & 91.3 & 0.1 \% & 91.3 & 91.3 & 2.32 & 41\end{array}$

\begin{tabular}{ll|lll}
$\mathrm{X} 1 * \mathrm{X} 3$ & 0.37 & 0.0
\end{tabular}

$\begin{array}{lllllll}1 & 68.6 & \begin{array}{l}0.37 \\ \%\end{array} & 68.6 & 68.6 & 8.27 & 08\end{array}$ 


\begin{tabular}{|c|c|c|c|c|c|c|c|}
\hline \multirow[t]{2}{*}{$\mathrm{X} 1 * \mathrm{X} 4$} & & & & & & & 0.9 \\
\hline & 1 & 0.1 & $0.0 \%$ & 0.1 & 0.1 & 0.01 & 15 \\
\hline \multirow[t]{2}{*}{$\mathrm{X} 1 * \mathrm{X} 5$} & & & & & & & 0.0 \\
\hline & 1 & 59.2 & 0.32 & 59.2 & 59.2 & 7.12 & 13 \\
\hline \multirow[t]{2}{*}{$\mathrm{X} 2 * \mathrm{X} 3$} & & & 002 & & & & 0.5 \\
\hline & 1 & 3.7 & $\%$ & 3.7 & 3.7 & 0.44 & 12 \\
\hline \multirow[t]{2}{*}{$\mathrm{X} 2 * \mathrm{X} 4$} & & & 013 & & & & 0.0 \\
\hline & 1 & 24.6 & $\%$ & 24.6 & 24.6 & 2.95 & 98 \\
\hline \multirow[t]{2}{*}{$\mathrm{X} 2 * \mathrm{X} 5$} & & & 0.07 & & & & 0.2 \\
\hline & 1 & 13.0 & $\%$ & 13.0 & 13.0 & 1.57 & 22 \\
\hline \multirow[t]{2}{*}{$\mathrm{X} 3 * \mathrm{X} 4$} & & & 0.01 & & & & 0.6 \\
\hline & 1 & 2.2 & $\%$ & 2.2 & 2.2 & 0.27 & 09 \\
\hline \multirow[t]{2}{*}{$\mathrm{X} 3 * \mathrm{X} 5$} & & & & & & & 0.2 \\
\hline & 1 & 10.9 & $\%$ & 10.9 & 10.9 & 1.31 & 63 \\
\hline \multirow[t]{2}{*}{$\mathrm{X} 4 * \mathrm{X} 5$} & & & 002 & & & & 0.4 \\
\hline & 1 & 4.5 & $\%$ & 4.5 & 4.5 & 0.55 & 67 \\
\hline Error & 25 & 208. & 1.12 & 208. & 8.3 & & \\
\hline \multirow{2}{*}{$\begin{array}{l}\text { Lack- } \\
\text { of-Fit }\end{array}$} & & 0 & 10 & 0 & & & \\
\hline & 20 & 203. & 1.10 & 203. & 10.2 & 12.5 & 0.0 \\
\hline \multirow{2}{*}{$\begin{array}{l}\text { Pure } \\
\text { Error }\end{array}$} & & & & & & & \\
\hline & 5 & 4.1 & $0.2 \%$ & 4.1 & 0.8 & & \\
\hline \multirow{4}{*}{ Total } & 45 & 185 & 100. & & & & \\
\hline & $4 J$ & 95.2 & $00 \%$ & & & & \\
\hline & & & R- & PRE & R- & & \\
\hline & $\mathrm{s}$ & R-sq & $\mathrm{sq}(\mathrm{a}$ & SS & $s q(p$ & & \\
\hline \multirow{3}{*}{$\begin{array}{l}\text { Model } \\
\text { Summ } \\
\text { ary }\end{array}$} & & & & & & & \\
\hline & 84 & 98.8 & 97.9 & 821. & 95.5 & & \\
\hline & 52 & $8 \%$ & $9 \%$ & 605 & $8 \%$ & & \\
\hline
\end{tabular}

The Minitab-17 program it was used to analyze the results of the zinc removal efficiency as a pilot relationship between the zinc removal efficiency and process variables was formulated through the quadratic model of the removal efficiency Zinc (RE) in terms of encoded units for process variables:
$\mathbf{R E} \%=125.6-2.596 \mathrm{X}_{1}+0.234 \mathrm{X}_{2}$ $0.0487 \mathrm{X}_{3}+1.76 \mathrm{X}_{4}-0.065 \mathrm{X}_{5}+0.011869 \mathrm{X}_{1}^{2}-$ $0.00057 \mathrm{X}_{2}^{2}+0.000027 \mathrm{X}_{3}^{2-}$

$0.153 \mathrm{X}_{4}^{2}+0.00134 \mathrm{X}_{5}^{2}+0.00366 \mathrm{X}_{1} \quad \mathrm{X}_{2}$ $+0.001037 X_{1} \quad X_{3}+0.0013 X_{1} X_{4}+0.00321 X_{1}$ $\mathrm{X}_{5}-0.000640 \mathrm{X}_{2} \mathrm{X}_{3}+0.0551 \mathrm{X}_{2} \quad \mathrm{X}_{4}-0.00401 \mathrm{X}_{2}$ $\mathrm{X}_{5}+0.00249 \mathrm{X}_{3} \mathrm{X}_{4}+0.000550 \mathrm{X}_{3} \mathrm{X}_{5}-0.0118 \mathrm{X}_{4}$ $\mathrm{X}_{5}$

Equation (4) shows Removal efficiency effect with variables (quadrated and linear). Increasing efficiency values increase with increasing values of positive coefficients depending on the laboratory scale, while removal efficiency decreases by increasing coefficients with negative values and the positive effect was found to be for the amount of CKD and $\mathrm{pH}$. The expected values of removal efficiency are listed in Table (1) according to the estimated values from equation (4).

ANOVA variance analysis was wont to test hypotheses about model coefficients which could be a statistical approach splits the full variation in a very group of information into individual parts given particular sources of variation to exam hypotheses on the parameters of the model [19,21].

ANOVA relies on the Fisher F- and P-test to figure out the adequacy. The massive value of $\mathrm{F}$ shows that the regression equation elucidates almost all of the variance within the response. The related $\mathrm{P}$-value is used for determining whether $\mathrm{F}$ is sufficiently high to point to statistical significance.

With a P-value less than 0.05, the model designated could be elucidated $98.88 \%$ of the variability [22]. Table 5 shows ANOVA for the response surface quadratic model. This table shows the sum of the square (SeqSS), degree of freedom (DF), adjusted sum of 
squares (Adj SS), adjusted mean of square (Adj MS), The value of $F$ is equal to 100.49 at $\mathrm{P}$ equal to 0.0001 percentage contribution (Cr. \%) of each parameter, F-value, and Pvalue. Shows Great importance for the regression model. Model fit quality was also validated by multiple correlations for the model.

In this case the value of the multiple correlation coefficients was $98.88 \%$ which indicates that this regression statistically significant, the model only explains $1.12 \%$ of all differences. Expected value Multiple correlation coefficient (former R2 $=95.58 \%$ ) in reasonable agreement with the value of the adjusted multiplier Correlation coefficient $(\mathrm{R} 2=97.99 \%)$.

ANOVA results showed that the mineral concentration contribution percentage is $66.03 \%$, which means that mineral concentration has the main effect on zinc removal efficiency. And the rest of the variables have close proportions. The linear term contains the main percentage of the contribution to the model by $77.3 \%$, followed by the interaction between the input variables with a contribution of $1.11 \%$ and it was small while the square contains a contribution of $20.47 \%$. The results confirm that the heavy metal concentration (zinc) is the most important factor.

\subsection{Effect of process variables on the zinc removal efficiency}

Figures (3-a, 3-b) show the effect of the primary concentration of zinc metal on its removal efficiency for different values of contact time (30, 60 and 90min.) and initial concentration of zinc $(20,60,100 \mathrm{ppm})$ at $\mathrm{pH} 5$ and the shaking rate of $200 \mathrm{rpm}$ and the concentration of barcode equal to $20 \mathrm{~g} / 1$. The figure 3-a represents response surface diagram while figure 3-b shows the corresponding contour diagram. From the surface plot, it is observed that at a contact time of 30 minutes, a decrease in the removal efficiency occurs with an increase in the initial zinc concentration. However, there was a slight change in the removal efficiency as the contact time approached 90 minutes. At a concentration of $100 \mathrm{ppm}$, the results show an increase in the efficiency of zinc removal with increasing contact time. Noting, at a concentration of 20 ppm, a significant change in removal efficiency occurred with increasing contact time, this was proven by the study [23].

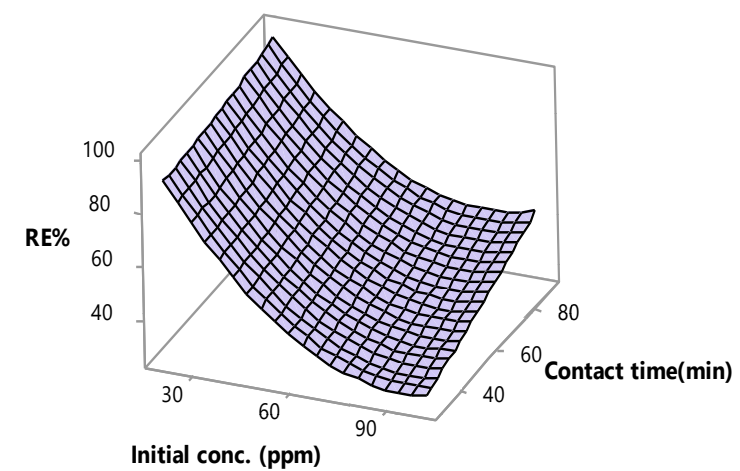

(a)

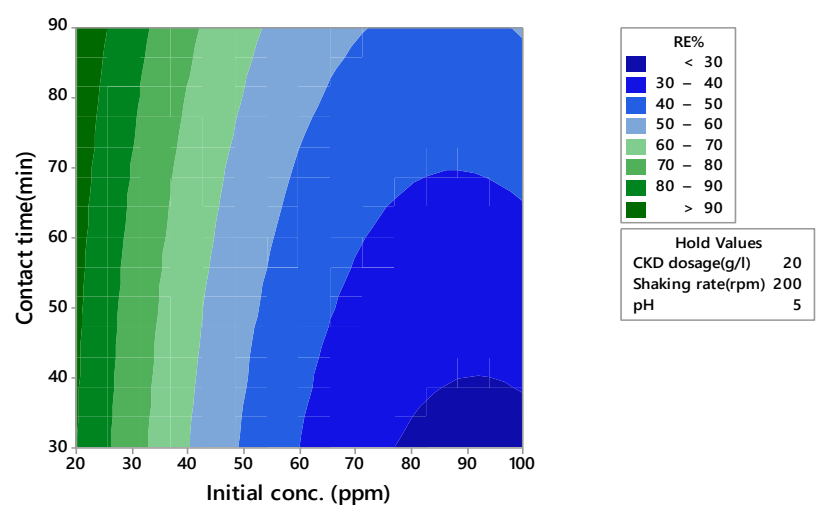

(b)

Figure 3: Response surface plot (a) and contour plot (b) showing the effect of contact time and initial concentration of zinc on the zinc removal efficiency

The effect of $\mathrm{pH}$ on zinc removal efficiency of different primary zinc concentrations $(20,60$ and $100 \mathrm{ppm})$ at different $\mathrm{pH}$ values $(2,5$, and 8$)$ at a constant rotation speed of $200 \mathrm{rpm}$, a 60-minute 
contact time and a CKD concentration of $20 \mathrm{~g} / 1$. This is illustrated in Figures $4 \mathrm{a}$ and $4 \mathrm{~b}$. The response surface plot (4a) shows that it currently has a slight impact on the zinc removal efficiency as it increases slightly with increasing $\mathrm{pH}$ while decreasing efficiency decreases with increasing concentration.

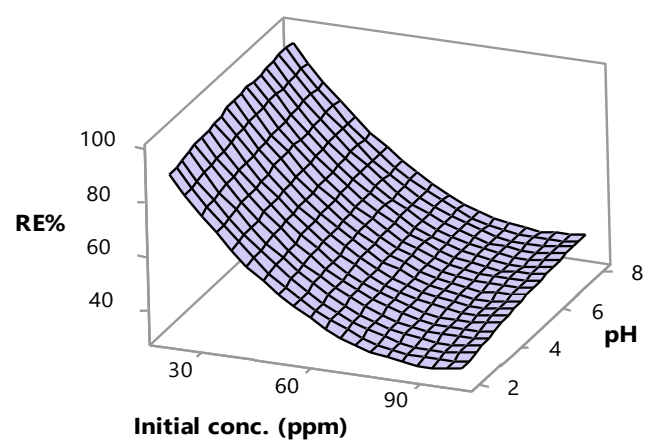

(a)

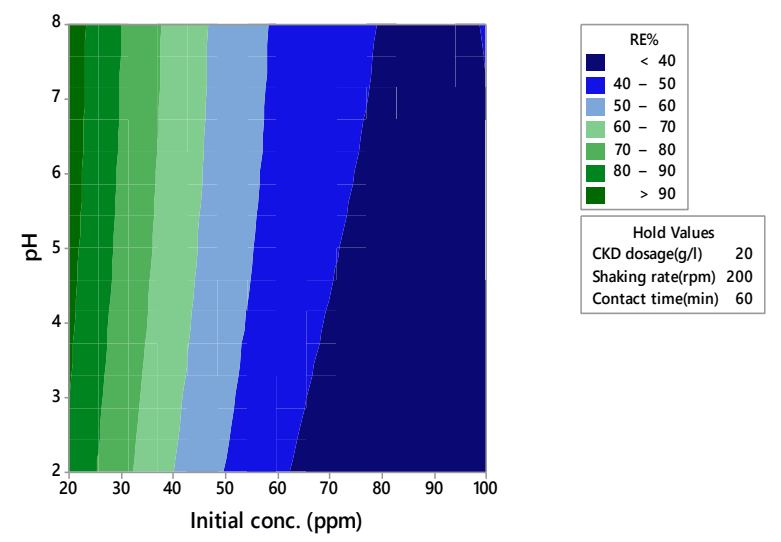

(b)

Figure 4: Response surface plot (a) and contour plot (b) showing the effect of the $\mathrm{pH}$ and initial concentration of zinc on the zinc removal efficiency

The corresponding contour piece (4-b) confirms that the maximum value of the zinc removal efficiency lies in a very small area; It had a $\mathrm{pH}$ equal to 8 and a zinc ion concentration of approximately $20 \mathrm{ppm}$.This was proven by the study[16,23,24].

As for the forms (5-a, 5-b), we show the relationship of the vibration rate with the initial concentration of zinc and its effect on the removal rate where the vibration rate was within $(100,200$ and $300 \mathrm{rpm})$ at an initial concentration of the zinc metal $(20,60$ and 100) ppm Response surface plot (5-a) currently has a significant effect on zinc removal efficiency as it increases as the shaking rate increases at $300 \mathrm{r} / \mathrm{min}$. While the removal efficiency decreased as the focus increased. The corresponding contour piece (5b) confirms that the maximum value of the zinc removal efficiency lies in a small area where the shaking rate is equal to $300 \mathrm{rpm}$ and the zinc ion concentration is around $20 \mathrm{ppm}$.

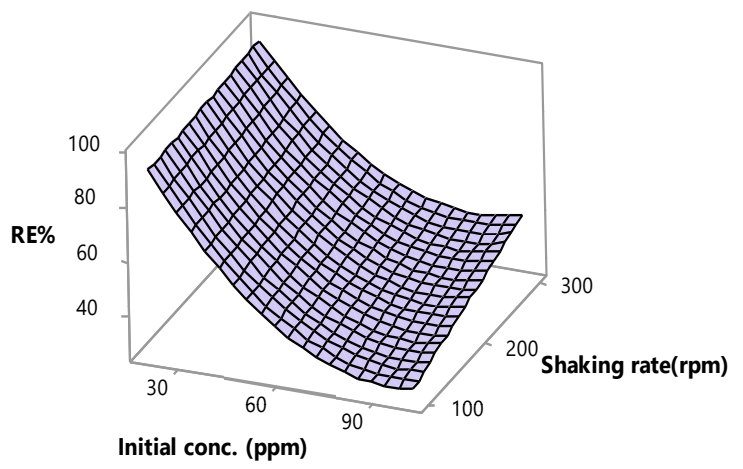

(a)

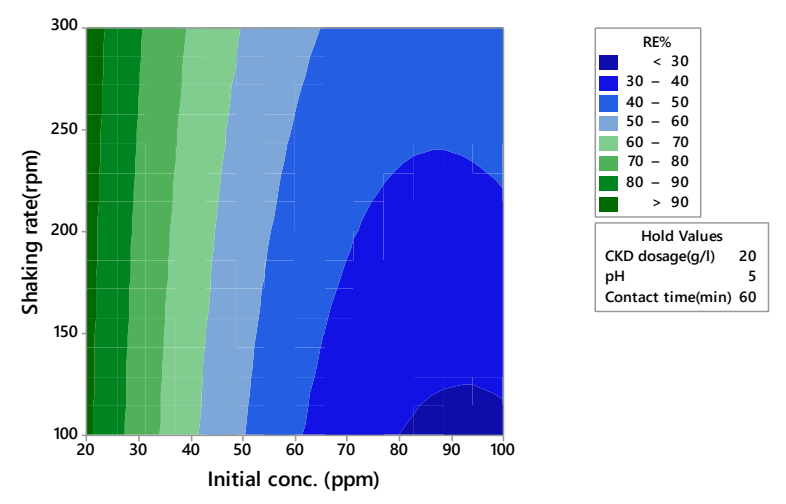

(b)

Figure 5: Response surface plot (a) and contour plot (b) showing the effect of shaking rate and initial concentration of zinc on the zinc removal efficiency

Figures (6-a,6-b) show us the effect of the CKD concentration with the initial concentration of zinc and its effect on the removal rate since the concentration of the to CKD was within $(5,20$ and 35) $\mathrm{g} / 1$ at an initial concentration of zinc metal $(20,60$ and 100) (ppm) The response surface plot (6-a) 
shows that it currently has a significant effect on zinc removal efficiency as it increases with increasing concentration of CKD at $35 \mathrm{~g} / 1$. While the removal efficiency decreased as the focus increased. The corresponding contour piece (6-b) confirms that the maximum value of zinc removal efficiency lies in a small area where the CKD concentration is about $35 \mathrm{~g} / 1$ and the zinc ion concentration is about $20 \mathrm{ppm}$.

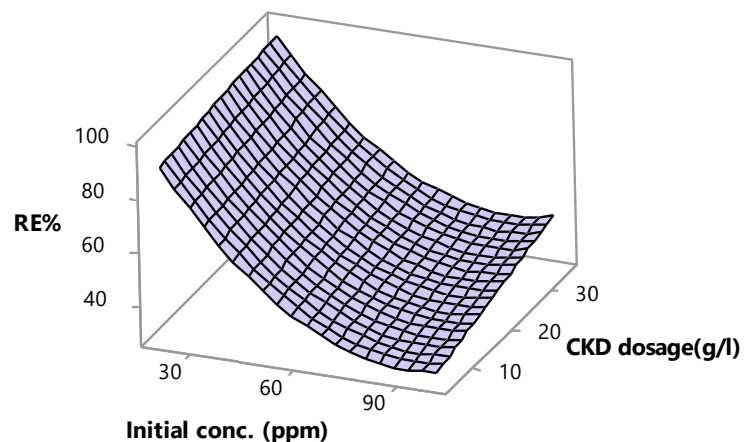

(a)

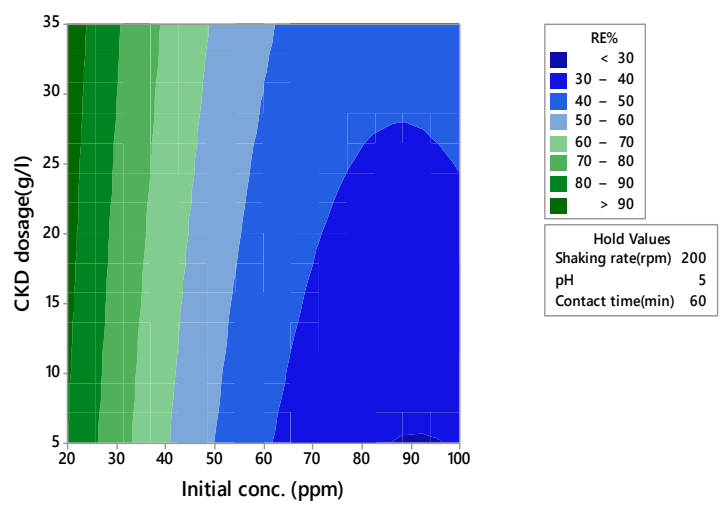

(b)

Figure 6: Response surface plot (a) and contour plot (b) showing the effect of CKD dosage and initial concentration of zinc on the zinc removal efficiency

\subsection{The optimization and confirmation test}

Numerical optimization of the software is applied to get the precise point that maximized the desirability function (DF). The desired goal was chosen by adjusting the weight or importance that could change the characteristics of the aim. Five options for the aim fields for response were selected: maximum, minimum, target, within range, and none. In the present work, the aim is to get higher removal efficiency of zinc so the 'maximum' field with corresponding 'weight'1.0 was chosen. $26.25 \%$ was taken as the lowest limit for the removal efficiency while $99.37 \%$ was taken as the upper limit. Under these settings and boundaries, the optimization procedure was conducted and the results are displayed in Table 6 with the desirability function of (1).

Results of optimization recommended using the initial concentration of zinc (20 ppm), a rotation speed of (300 rpm), PH (8), contact time (90 $\mathrm{min})$, and CKD dosage (35 $\mathrm{gll})$ to get higher removal efficiency of $100.6 \%$.

Two experiments at the optimum values of the process parameters were performed to confirm the results of optimization. $20 \mathrm{ppm}$ was taken as nearly the value of the initial zinc concentration resulted from optimization. The results are displayed in Table 4. After $90 \mathrm{~min}, 300 \mathrm{rpm}, \mathrm{pH} 8$ and CKD dosage gll of the experiments, the results are shown in Table 4.

A removal efficiency of $99.3 \%$ was acquired which is within the zone of the expected optimum value of removal efficiency that was acquire from optimization analysis.

Using desirability functions (Table 6).

Table 6.Optimum of process parameters for maximum removal efficiency of zinc

\begin{tabular}{|c|l|l|l|l|}
\hline Response & Fit & SE Fit & $\begin{array}{c}95 \% \\
\text { CI }\end{array}$ & $\begin{array}{c}95 \% \\
\text { PI }\end{array}$ \\
\hline RE\% & 106.08 & 5.27 & $\begin{array}{c}(95.21 ; \\
116.94)\end{array}$ & $\begin{array}{c}(93.70 ; \\
118.46)\end{array}$ \\
\hline
\end{tabular}




\begin{tabular}{|c|c|c|c|c|c|c|c|}
\hline $\begin{array}{l}\text { Respon } \\
\text { se }\end{array}$ & Goal & $\begin{array}{l}\text { Lo } \\
\text { wer }\end{array}$ & \multicolumn{2}{|c|}{ Target } & $\begin{array}{l}\text { Uppe } \\
\text { r }\end{array}$ & $\begin{array}{l}\text { Wei } \\
\text { ght }\end{array}$ & $\begin{array}{c}\text { Impo } \\
\text { rtanc } \\
\mathrm{e}\end{array}$ \\
\hline RE\% & $\begin{array}{l}\text { Maxi } \\
\text { mum }\end{array}$ & $\begin{array}{c}26.2 \\
5\end{array}$ & \multicolumn{2}{|c|}{99.37} & 99.37 & 1 & 1 \\
\hline 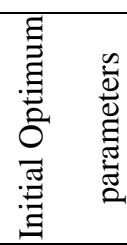 & 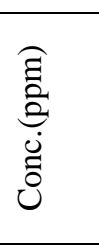 & $\begin{array}{l}0 \\
0 \\
\tilde{\Xi} \\
0 \\
0 \\
0 \\
0 \\
0\end{array}$ & 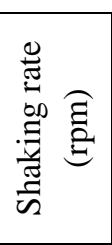 & 责 & 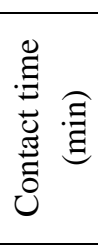 & 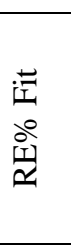 & 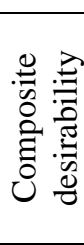 \\
\hline RE\% & 20 & 35 & 300 & 8 & 90 & $\begin{array}{l}106 . \\
078\end{array}$ & 1 \\
\hline
\end{tabular}

Table 7. Confirmation of the optimum conditions for zinc removal efficiency

\begin{tabular}{|c|c|c|c|c|c|c|c|}
\hline RUN & $\begin{array}{c}\text { Initial } \\
\text { conc. } \\
\text { (ppm) }\end{array}$ & $\begin{array}{c}\text { CKD } \\
\text { dosag } \\
\mathrm{e}(\mathrm{g} / \mathrm{l})\end{array}$ & $\begin{array}{c}\text { Shaki } \\
\text { ng } \\
\text { rate(r } \\
\mathrm{pm})\end{array}$ & $\begin{array}{c}\mathrm{P} \\
\mathrm{H}\end{array}$ & $\begin{array}{c}\text { Con } \\
\text { tact } \\
\text { tim } \\
\mathrm{e}(\mathrm{m} \\
\text { in })\end{array}$ & $\begin{array}{c}\text { Actua } \\
1\end{array}$ & $\begin{array}{c}\text { Av } \\
\text { era } \\
\text { ge }\end{array}$ \\
\hline $\begin{array}{c}\text { RUN } \\
1\end{array}$ & 20 & 35 & 300 & 8 & 90 & 99.3 & $\begin{array}{c}99.3 \\
25\end{array}$ \\
\hline $\begin{array}{c}\text { RUN } \\
2\end{array}$ & 20 & 35 & 300 & 8 & 90 & 99.35 & $\begin{array}{c}99.3 \\
25\end{array}$ \\
\hline
\end{tabular}

\section{Conclusions}

It has been demonstrated that the removal of zinc from a simulated solution of wastewater can be successfully performed using CKD as an absorbent material. The RSM methodology is applied effectively to improve process parameters and to know the optimum levels of these parameters for zinc removal resulting in increased removal efficiency. Based on RSM analysis, it can be concluded that it zinc concentration has the greatest influence on the efficiency of zinc removal compared to other factors. The optimum values obtained from the improvement were a preliminary $\mathrm{Zn}$ (II) concentration of $20 \mathrm{ppm}, \mathrm{pH} \mathrm{8}$, a spin speed of $300 \mathrm{rpm}$, a 90-minute contact time and a CKD dose of $35 \mathrm{~g} / \mathrm{l}$. Under these conditions, it may be possible to reduce the concentration of $\mathrm{Zn}$ (II) from
$20 \mathrm{ppm}$ to less than $0.2 \mathrm{ppm}(\mathrm{RE}=99.3 \%)$ at a time of 90 minutes.

\section{Acknowledgements}

The authors wish to acknowledge the helpful and technical assistance given by the organism of the Chemical Engineering Department, College of Engineering- University of AlQadisiyah.

\section{Conflict of interest}

The authors confirmed that there is no conflict of interest in this research, but it is the product of a special scientific work for researchers only.

\section{References}

1] EL ZAYAT, Mohamed; ELAGROUDY, Sherien; EL HAGGAR, Salah. Equilibrium analysis for heavy metal action removal using cement kiln dust. Water science and technology, 2014, 70.6: 1011-1018.

2] MAHAJAN, G.; SUD, D. Accessing the potential of lignocelluloses agricultural waste biomass for removal of $\mathrm{Ni}$ (II) metal ions from aqueous streams. International Journal of Scientific \& Engineering Research, 2013, 4.4: 1713-1720.

3] BAILEY, Susan E., et al. A review of potentially low-cost sorbents for heavy metals. Water research, 1999, 33.11: 24692479.

4] SUD, Dhiraj; MAHAJAN, Garima; KAUR, M. P. Agricultural waste material as potential adsorbent for sequestering heavy metal ions from aqueous solutions-A review. Bio resource technology, 2008, 99.14: 6017-6027.

5] DEMIRBAS, Ayhan. Heavy metal adsorption onto agro-based waste materials: a review. Journal of hazardous materials, 2008, 157.2-3: 220-229. 
6] CHIBAN, Mohamed, et al. Application of low-cost adsorbents for arsenic removal: A review. Journal of Environmental Chemistry and Ecotoxicology, 2012, 4.5: 91-102.

7] DAVE, Pragnesh N.; PANDEY, Nishtha; THOMAS, Hannah. Adsorption of $\mathrm{Cr}$ (VI) from aqueous solutions on tea waste and coconut husk. 2012. 19:111-117

8] MUSTAFA, Yasmen A.; SHABAN, Mohammad Ali Akrim Ali. Treatment of Wastewater by Cement Kiln Dust. Association of Arab Universities Journal of Engineering Sciences, 2017, 24.2: 31-46.

9] RAHMAN, M. K., et al. Literature review on cement kiln dust usage in soil and waste stabilization and experimental investigation. International Journal of Research and Reviews in Applied Sciences, 2011, 7.1: 77-87.

10] CORUH, S.; ELEVLI, S. Optimization study of dye removal by cement kiln dust using the central composite design of experiments. Global NEST Journal, 2015, 17.1: 93-102.

11] W. S. Adaska, P.E. and D. H. Taubert, "Beneficial Uses of Cement Kiln Dust," 2008 IEEE Cement Industry Technical Conference Record, Miami, FL, 2008, pp. 210-228, doi: 10.1109/CITCON.2008.24.

12] M. A. Bezerra, R. E. Santelli, E. P. Oliveira, L. S. Villar, and L. A. Escaleira, "M.A. Bezerra, R.E. Santelli, E.P. Oliveira, L.S. Villar, L.A. Escaleira, 'Response surface methodology (RSM) as a tool for optimization in analytical chemistry,' Talanta 76(5), 965-77, 2008.," Talanta, vol. 76, no. 5, pp. 965-977, 2008.

13] KLIMANTAVIÈIÛTË, Margarita Giedrutë, et al. Interaction of heavy metal ions with cement kiln dust. Ekologija, 2005, 1: 3136.

14] AMIN, Abu El-Eyuoon Abu Zied; SELMY, Salman AH. Effect of $\mathrm{pH}$ on removal of $\mathrm{Cu}, \mathrm{Cd}, \mathrm{Zn}$, and $\mathrm{Ni}$ by cement kiln dust in aqueous solution. Communications in soil science and plant analysis, 2017, 48.11: 13011308.

15] TARLEY, César Ricardo Teixeira, et al. Chemo metric tools in electro analytical chemistry: methods for optimization based on factorial design and response surface methodology. Micro chemical journal, 2009, 92.1: 58-67.

16] RAHMAN, M. K., et al. Literature review on cement kiln dust usage in soil and waste stabilization and experimental investigation. International Journal of Research and Reviews in Applied Sciences, 2011, 7.1: 77-87.

17] HUIPING, Li, et al. Technologic parameter optimization of gas quenching process using response surface method. Computational Materials Science, 2007, 38.4: 561-570..

18] M. Evans, Optimization of manufacturing processes: a response surface approach, vol. 791. Maney Pub, 2003.

19] ABBAR, Ali H.; SALMAN, Rasha H.; ABBAS, Ammar S. Cadmium removal using a spiral-wound woven wire meshes packed bed rotating cylinder electrode. Environmental technology \& innovation, 2019, 13: 233-243.

20] Y.-D. Chen, W.-Q. Chen, B. Huang, and M.-J. Huang, "Process optimization of K2C2O4-activated carbon from kenaf core using Box-Behnken design," Chem. Eng. Res. Des., vol. 91, no. 9, pp. 1783-1789, 2013.

21] SEGUROLA, Juan, et al. Design of eutectic photo initiator blends for UV/visible curable acrylate printing inks and coatings. Progress in Organic Coatings, 1999, 37.1-2: 23-37.

22] EL-AWADY, M. H.; SAMI, T. M. Removal of heavy metals by cement kiln dust. Bulletin of environmental contamination and toxicology, 1997, 59.4: 603-610. 
23] BAES JR, C. F.; MESMER, R. E. The first transition series vanadium. The Hydrolysis of Cautions, 1976, 193-210.

24] MACKIE, Allison L.; WALSH, Margaret E. Bench-scale study of active mine water treatment using cement kiln dust (CKD) as a neutralization agent. Water research, 2012, 46.2: $327-334$. 